\title{
PENGARUH LATIHAN SOCCER LIKE GAMES TERHADAP PENINGKATAN KETERAMPILAN PASSING DALAM PERMAINAN SEPAKBOLA
}

\author{
Indrayogi ${ }^{1}$ dan Rudi $^{2}$ \\ Universitas Majalengka, Indonesia \\ email:indrayogi@unma.ac.id
}

\begin{abstract}
ABSTRAK. Dalam penelitian ini akan meneliti pengaruh latihan soccer like games terhadap dasar sepakbola di SMPN 1 Sukahaji Majalengka. Tujuan penelitian ini adalah untuk mengetahui seberapa besar pengaruh latihan soccer like games terhadap keterampilan dasar sepakbola. Untuk penelitian ini metode yang digunakan adalah metode eksperimen, dengan desain penelitian Pre-test Post-test control group design. Instrumen penelitian yang digunakan adalah tes keterampilan passing. Berdasarkan hasil penghitungan dan pengujian signifikan eksperimen, ternyata eksperimen lebih memberikan pengaruh yang signifikan terhadap hasil belajar passing, dalam permainan sepakbola di SMPN 1 Sukahaji Majalengka. Hal ini terlihat dari hasil passing eksperimen dengan nilai $(2,87)>(2,048)$. Sebagai saran dari peneliti untuk pembelajaran dalam kegiatan pembelajaran pendidikan jasmani disekolah dapat menerapkan pembelajaran soccer like games sebagai alternatif atau solusi, karena pembelajaran ini tepat untuk digunakan pada siswa pemula karena tugas gerak yang diberikan sesuai dengan tahap perkembangan siswa. Selain itu pembelajaran soccer like games memberikan pengaruh yang signifikan terhadap hasil keterampilan passing dalam permainan sepakbola di SMPN 1 Sukahaji Majalengka.
\end{abstract}

Kata Kunci: Latihan; Soccer Like Game; Sepakbola.

\section{Pendahuluan}

Pembelajaran Penjas pada saat ini, sebagian siswa-siswi di sekolah menganggap tidak penting dan selalu beranggapan bahwa hanya membuat siswa menjadi lelah dan tidak bersemangat untuk mengikuti pembelajaran bidang studi lainnya, sehingga pembelajaran ini kurang disenangi karena dinilai tidak penting oleh siswa. Ini merupakan suatu anggapan yang salah apabila kita mengkaji lebih dalam mengenai hakikat pendidikan jasmani. Sebab dalam pendidikan jasmani dijelaskan bahwa seluruh domain yang terdapat didalam pendidikan akan dapat dikembangkan seperti domain psikomotor, kognitif, dan tentu saja domain afektif yang berkaitan dengan sikap perilaku siswa. Untuk itu, diharapkan didalam permainan soccer like games yang didominasi dengan aktifitas fisik ini dapat menumbuhkembangkan seluruh potensi yang dimiliki siswa diatas. Didalam kurikulum pembelajaran pendidikan jasmani yang dikembangkan di sekolah terdapat beberapa materi pembelajaran yang diajarkan kepada siswa sebagai bentuk untuk mencapai tujuan yang telah dicanangkan. Menurut (Depdik, 2003) menjelaskan bahwa: "Ruang lingkup materi pendidikan jasmani anatar lain adalah mata pelajaran permainan dan olahraga, aktivitas pengembangan, uji diri/senam, aktivitas ritmik, akuatik (aktivitas air) dan pendidikan luar kelas (outdoor education).”. 
Hampir seluruh siswa di sekolah menyenangi permainan ini mulai dari tingkat SD, SMP, sampai siswa SMA karena permainan sepakbola sangat mudah di mainkan namun lebih menuntut keterampilan yang sangat kompleks. Cabang olahraga sepakbola merupakan permainan yang dimainkan oleh dua tim, masing- masing tim beranggotakan sebelas orang termasuk di antaranya penjaga gawang. Dalam hal ini Sucipto, dkk (2000) menjelaskan bahwa: "Sepakbola merupakan permainan beregu, masing-masing regu terdiri dari sebelas pemain, dan salah satunya penjaga gawang. Permainan ini hampir seluruhnya dimainkan dengan menggunakan tungkai, kecuali penjaga gawang yang dibolehkan menggunakan lengannya di daerah tendangan hukumannya".

Permainan ini juga diharapkan memberikan sumbangsi terhadap motivasi siswa untuk menampilkan gerakan yang lebih baik pada proses kegiatan pembelajaran berikutnya. Pengaruh latihan soccer like games yang merupakan permainan tim dan individu dapat menciptakan suatu kegiatan belajar yang berupaya untuk memecahkan masalah baik dari kompetensi suatu tugas gerak maupun suatu kemampuan sosial yang timbul akibat interaksi didalam proses permainan tersebut. Pembelajaran permainan soccer like games juga diharapkan dapat menciptakan suatu suasana pembelajaran yang menyenangkan sehingga dapat membuat kesan yang menyenangkan serta kegembiraan yang dapat membantu memberikan penyegaran terhadap kepenetan otak siswa dalam mengikuti pembelajaran lain disekolah.

\section{Keterampilan Dasar Sepakbola}

Pelaksanaan keterampilan sepakbola membutuhkan waktu yang cukup panjang agar terampil dalam bermain bola. Teknik dasar sepakbola berarti pola gerak yang mendasari permainan sepakbola. Seperti yang dikemukakan Sukatamsi (1992) bahwa "teknik dasar melakukan gerakan-gerakan yang tidak lepas sama sekali dari permainan sepakbola" Untuk dapat bermain sepakbola dengan baik pemain dibekali dengan pola keterampilan dasar yang baik. Pemain yang memiliki teknik dasar yang baik cenderung pemain tersebut dapat bermain sepakbola dengan baik pula.

Dari paparan diatas keterampilan gerak dasar berperan penting dalam permainan sepakbola karena untuk bermain permainan sepakbola pemain dituntut harus menguasai seluruh gerak dasar sepakbola. Namun dalam permainan sepakbola teknik yang paling dominan dilakukan adalah menendang bola. Hal ini sesuai dengan pendapat Sucipto dkk, (2000) yang mengungkapkan bahwa: Menendang bola merupakan salah satu karakteristik permainan sepakbola yang paling dominan. Pemain yang memiliki teknik menendang dengan baik, akan dapat bermain secara efisien. Tujuan menendang bola adalah untuk 
mengumpan (passing), menembak ke gawang (shooting at the goal), dan menyapu untuk menggagalkan serangan lawan (sweeping). Dilihat dari perkenaan bagian kaki ke bola, menendang dibedakan beberapa macam, yaitu menendang dengan kaki bagian dalam (inside), kaki bagian luar (outside), punggung kaki (instep), dan punggung kaki bagian dalam (inside of the instep).

Tujuan menghentikan bola untuk mengontrol bola, yang termasuk dalamnya untuk mengatur tempo permainan, mengalihkan laju permainan dan memudahkan untuk passing.

1) Menghentikan bola dengan kaki bagian dalam Sucipto, dkk (2000) mengemukakan tentang teknik menghentikan bola dengan kaki bagian dalam sebagai berikut: Pada umumnya digunakan untuk menghentikan bola yang datangnya menggelinding, bola pantul ke tanah, dan bola di udara sampai setinggi paha. Analisis menghentikan bola dengan kaki bagian dalam adalah sebagai berikut: (1) Posisi badan segaris dengan datangnya bola, (2) Kaki tumpu mengarah pada bola dengan lutut sedikit ditekuk, (3) Kaki penghenti diangkat dengan permukaan bagian dalam kaki dijulurkan ke depan segaris dengan datangnya bola, (4) Bola menyentuh kaki persis di bagian dalam kaki atau mata kaki, (5) Kaki penghenti mengikuti arah bola, (6) Pandangan mengikuti jalannya bola sampai bola berhenti, (7) Kedua lengan dibuka di samping badan untuk menjaga keseimbangan.

2) Menghentikan bola dengan kaki bagian luar Sucipto, dkk (2000) mengemukakan teknik menghentikan bola dengan kaki bagian luar sebagai berikut: Pada umumnya digunakan untuk menghentikan bola yang datangnya menggelinding, bola pantul ke tanah, dan bola di udara sampai setinggi paha. Analisis menghentikan bola dengan kaki bagian luar adalah sebagai berikut : (1) Posisi badan menghadap ke datangnya bola, (2) Kaki tumpu berada di samping kurang lebih 30 derajat dan garis datangnya bola dengan lutut sedikit ditekuk, (3) kaki penghenti diangkat sedikit dengan permukaan kaki bagian luar dijulurkan ke depan menjemput datangnya bola, (4) bola menyentuh kaki tepat di permukaan kaki bagian luar, (5) pada saat kaki menyentuh bola, kaki penghenti mengikuti arah bola sampai berada di bawah badan atau terkuasai, (6) posisi lengan berada di samping badan untuk menjaga keseimbangan.

3) Menghentikan bola dengan punggung kaki Sucipto, dkk (2000) mengemukakan teknik menghentikan bola dengan punggung kaki sebagai berikut: Pada umumnya digunakan untuk menghentikan bola di udara sampai setinggi paha. Analisis menghentikan bola dengan punggung kaki adalah sebagai berikut: (1) posisi badan menghadap datangnya bola, (2) kaki tumpu berada di samping kurang lebih $15 \mathrm{~cm}$ dan garis datangnya bola dengan lutut sedikit ditekuk, (3) kaki penghenti di angkat dan dijulurkan ke depan menjemput 
datangnya bola, (4) kaki menyentuh bola tepat di punggung kaki, (5) pada saat kaki menyentuh bola, kaki penghenti mengikuti arah bola sampai berhenti di badan atau terkuasai.

4) Menghentikan bola dengan telapak kaki Pada umumnya digunakan untuk menghentikan bola pantul dari tanah. Seringkali kita juga melihat pemain sepak bola menghentikan bola datar dengan telapak kaki dengan jalan bola kencang. Analisis menghentikan bola dengan telapak kaki menurut Sucipto, dkk, (2000) adalah sebagai berikut: (1) posisi badan lurus dengan arah datangnya bola, (2) kaki tumpu berada di samping kurang lebih 15 cm dan garis datangnya bola dan lutut sedikit ditekuk, (3) kaki penghenti diangkat sedikit dengan telapak kaki dijulurkan menghadap sasaran, (4) pada saat bola masuk ke kaki, ujung kaki diturunkan sehingga bola berhenti di depan badan, (5) Pandangan mengikuti arah bola sampai bola berhenti.

\section{Belajar dan Pembelajaran}

Pada hakikatnya belajar merupakan suatu usaha secara sadar yang dilakukan agar terjadi perubahan perilaku dalam diri seseorang baik berupa pengetahuan dan keterampilan sebagai hasil dari proses belajar. Pernyataan tersebut diperkuat oleh Suryabrata (1974) yang dikutip Mahendra (2007) yang menyatakan "belajar merupakan upaya sengaja untuk memperoleh perubahan tingkah laku, baik yang berupa perubahan tingkah laku yang didapatkan dari proses belajar merupakan salah satu bentuk interaksi dengan lingkungan belajar. Menurut Hamalik (2003) menyatakan bahwa "belajar adalalah individu melalui interaksi dengan lingkungan". Dari pendapat merupakan perubahan perilaku pada diri seseorang menuju ke arah yang lebih baik dalam hubungannya dengan lingkungan belajar. Proses perubahan tersebut akan menjadi pengalaman bagi si pelaku.

Berdasarkan pendapat diatas jelaslah belajar harus memiliki tujuan yang jelas dan dilaksanakan secara sistematis dan terprogram. Dimana tujuan belajar bukan hanya menitikberatkan pada satu aspek saja melainkan keseluruhan aspek. Sejalan dengan pernyataan diatas Dimyati dan Mudjiono (2006) mengungkapkan bahwa "belajar merupakan yang terlibat dalam proses internal tersebut adalah seluruh mental yang meliputi ranah ranah kognitif, afektif dan psikomotori harus melibatkan aspek pengetahuan (kognitif), aspek keterampilan (psikomotor) dan aspek sikap (afektif), sehingga proses perubahan perilaku yang terjadi melibatkan aspek pengetahuan, keterampilan dan sikap.

Proses belajar yang telah dilakukan tentunya bertujuan untuk mencapai hal yang telah dicanangkan sebelumnya. Proses belajar bisa dikatakan sukses apabila memenuhi beberapa 
kriteria tertentu. Sejalan dengan pernyataan tersebut Pribadi (2009) mengungkapkan bahwa: Proses belajar dapat disebut sukses apabila memenuhi kriteria sebagai berikut, yakni seseorang melakukan interaksi dengan sumber belajar secara intensif, melakukan latihan untuk penguasaan kompetensi memperoleh umpan balik segera setelah melakukan proses belajar, menerapkan kemampuan dalam konteks nyata, dan melakukan interaksi dalam memperoleh pengetahuan dan keterampilan.

Berkaitan dengan pembelajaran, Hamalik (2003) menjelaskan, "Pembelajaran adalah suatu kombinasi-unsur yang manusiawi, material, fasilitas, perlengkapan dan prosedur yang saling mempengaruhi dalam mencapai tujuan pembelajaran”. Lebih lanjut lagi Hamalik (2003) mengemukakan sebagai berikut: Pembelajaran adalah upaya menyampaikan pengetahuan kepada peserta didik/siswa. Berkenaan dengan pembahasan pembelajaran, menurut UndangUndang Sistem Pendidikan Nasional No 20 Tahun 2003 menjelaskan bahwa: Pembelajaran adalah proses interaksi peserta didik dengan pendidik dan sumber belajar pada suatu lingkungan belajar. Pembelajaran sebagai proses yang meningkatkan kemampuan berfikir siswa, serta dapat meningkatkan kemampuan mengkonstruksi pengetahuan baru sebagai upaya meningkatkan penguasaan yang baik terhadap materi pembelajaran.

Dalam rangka mencapai pembelajaran yang baik suatu proses pembelajaran harus mencakup beberapa prinsip-prinsip pembelajaran yang tepat. Menurut Dimyati dan Mudjiono (2006) menyatakan: pembelajaran meliputi perhatian dan motivasi, keaktifan siswa, keterlibatan langsung, pengulangan, tantangan, balikan serta penguatan serta perbedaan individual".

Berdasarkan pendapat diatas, proses pembelajaran yang berkualitas tidak hanya cukup didukung dengan kreatifitas tenaga pengajar, lebih dari itu dibutuhkan juga timbal balik berupa motivasi pelajar itu sendiri. Ketika terjadi keselarasan diantara motivasi pelajar yang tinggi kemudian ditunjang dengan kreatifitas pengajar yang mampu memfasilitasi motivasi tersebut maka akan membawa pada keberhasilan pencapaian target belajar. Pencapaian suatu target belajar sekilas dapat dilihat dari melalui perubahan sikap dan kemampuan siswa pada saat melalui proses belajar.

\section{Pembelajaran Sepakbola di Sekolah}

Sepakbola merupakan salah satu olahraga permainan yang banyak digemari oleh masyarakat dan banyak dimainkan oleh seluruh lapisan masyarakat Indonesia, baik anak-anak, remaja atau orang dewasa bahkan wanita sekalipun. Sepakbola merupakan salah satu cabang olahraga 
yang tercantum dalam kurikulum pada jenjang pendidikan SD, SMP, SMA dan sampai Perguruan Tinggi.

Pembelajaran sepakbola tidak sepenuhnya bisa dilakukan dengan maksimal di setiap sekolah, hal ini timbul dikarenakan setiap sekolah tidak memiliki fasilitas pendukung pembelajaran yang memadai. Fasilitas tersebut diantaranya tidak memiliki area lapangan yang luas, kurangnya alat-alat yang digunakan dalam permainan sepakbola. Berdasarkan hal ini tentunya perlu inovasi dan modifikasi pembelajaran agar siswa bisa merasakan pembelajaran sepakbola yang sebenernya tanpa menghilangkan intisari dari sepakbola itu sendiri. Kondisi kekurangan fasilitas mengakibatkan siswa hanya mendapat kesempatan yang sedikit dalam melakukan gerakan dan tentunya hasil yang diinginkan tidak akan memuaskan.

Berangkat dari hal itu guru penjas memegang peranan penting untuk membuat modifikasi pembelajaran sepakbola dengan tidak menghilangkan gerakan dasar dari sepakbola, salah satu modifikasi yang dapat dilakukan untuk mengatasi hal tersebut merupakan bentuk modifikasi dari pembelajaran sepakbola yang merupakan bentuk-bentuk permainan yang menyerupai sepakbola. Keuntungan dengan menggunakan pembelajaran ini sekolah tidak perlu memiliki lapang yang luas, peralatan yang banyak, karena soccer like games bisa dimodifikasi sesuai keinginan dan kebutuhan.

\section{Soccer Like Games}

Berdasarkan karakteristik permainannya soccer like games termasuk kedalam permainan invasi (penyerangan). Lebih lanjut Bahagia (2011) memberikan pengertiannya: Hakikat permainan invasi adalah menguasai atau mempertahankan obyek permainan agar selalu ada pada regunya dengan jalan melakukan operan-operan (passing) untuk mendapatkan obyek permainan dari regu lawan dengan jalan menghadang, menghambat atau merebutnya untuk mencegah gol.

Dalam pelaksanaannya permainan soccer like games selalu dikaitkan dengan sepakbola, karena pada dasarnya permainan soccer like games sendiri adalah suatu pengembangan dari permainan sepakbola sebenarnya yang didesain untuk proses pembelajaran penjas di sekolah yang memiliki unsur-unsur pendidikan agar siswa dapat memiliki intelektualitas yang baik dan sikap terpuji serta memiliki kebugaran jasmani dan keterampilan yang baik. Didalam permainan soccer like games aktivitasnya dapat dimodifikasi baik peraturan, bola yang digunakan, lapangan, cara membuat skor, jenis permainan, cara memulai permainan, jumlah pemain yang bermain. Objek permainan yang digunakan dalam permainan ini bisa beragam, mulai dari bola sepak yang standar, bola karet bahkan bola modifikasi yang terbuat dari anyaman dapat digunakan dalam permainan ini. 
Keuntungan yang didapat dari soccer like games ini adalah aturan yang fleksibel sehingga dapat memfasilitasi setiap kemampuan siswa. Disamping itu, soccer like games dapat dilakukan dimanapun dengan peraturan, lapang, alat yang fleksibel dalam menunjang setiap keterampilan gerak peserta didik.

Soccer Like Games yang merupakan permainan tim dan individu dapat menciptakan suatu kegiatan belajar yang berupaya untuk memecahkan masalah baik dari kompetensi suatu tugas gerak maupun suatu kemampuan sosial yang timbul akibat interaksi didalam proses permainan tersebut. Permainan soccer like games juga diharapkan dapat menciptakan suasana belajar yang menyenangkan sehingga dapat membuat kesan yang menyenangkan serta kegembiraan yang dapat membantu memberikan penyegaran terhadap kepenatan otak siswa dalam mengikuti pembelajaran lain di sekolah.

Soccer Like Games tentunya memiliki tujuan yang hendak dicapai. Hasil tujuan tersebut tentunya berkaitan dengan tujuan dari penidikan jasmani, dimana soccer like games untuk peningkatan kemampuan motorik siswa (psikomotor), pemahaman siswa (cognitif) serta keterampilan emosional (afektif). Tujuan tersebut sesuai dengan tujuan penjas, dimana tujuan penjas seperti yang diungkapkan Mahendra (2009) yaitu dalam tujuan pebelajarannya meliputi domain afektif, kognitif dan psikomotor.

\section{Bentuk Permainan Soccer Like Games}

Soccer Like Games selalu dikaitkan dengan bermain sepakbola sehingga dalam pelaksanaannya tidak terlepas dari cara bermain sepakbola secara umum. Dalam proses pembelajaran di sekolah soccer like games merupakan bentuk modifikasi dari permainan sepakbola, dimana cara bermainnya bisa dimodifikasi baik peraturan, bola yang digunakan, lapangan, cara membuat skor, jenis permainan, cara memulai permainan, jumlah pemain yang bermain. Objek permainan yang digunakan dalam permainan ini bervariasi dari mulai bola sepak standar, bola karet bahkan bola modifikasi yang terbuat dari anyaman. Bentuk soccer like games dapat dimodifikasi dari jumlah pemain yang mengikuti permainan. Area lapangan bisa dimodifikasi menjadi bentuk sesuai dengan kondisi luas lapangan dan disesuaikan dengan kebutuhan pemain dalam satu permainan. Dalam satu permainan bisa dimodifikasi dengan banyaknya cara untuk menghasilkan skor agar mempermudah pemain mendapat skor.

\section{Bermain 3 versus 1 (Levelling Sistem)}

Tiga orang bermain passing sedangkan yang seorang berupaya merebut bola tersebut, antara ke tiga orang tersebut kita dapat menentukan siapa yang harus melakukan passing langsung tanpa stop dulu, dan siapa yang boleh menyetop bola terlebih dahulu. 


\section{Permainan Rhondo Sepakbola}

Permainan seperti futsal (indoor) dengan memakai satu orang joker (camelium). Permainan bisa diawali dari 3-3 plus camelium; dan 3-6 dengan menempatkan 2 pemain bersebelahan diluar daerah permainan. Permainan bisa dikembangkan jika daerah permainan cukup luas, menjadi 8-5 dengan 1 orang menjadi camelium. Permainan juga bisa dikembangkan jika pemain diluar menerima operan bola dari pemain didaeerah permainan, maka dianggap telah goal". Pemain terjadi yang berperan sebagai "camelium mambantu kedua tim. Sesuai dengan tim mana yang menguasai bola, untuk membantu mencetak goal atau poin.

\section{Permainan sepakbola dua gawang}

Permainan ini menyerupai permainan rhondo sepakbola, tetapi gawang ditempatkan didaerah permainan dengan empat gawang kecil (bisa menggunakan tiang/patok berukuran kecil). Pemain memiliki kesempatan untuk menciptakan "goal" pada salah satu-nya daridaridepan, tetapi dua tidak gawang diperkenankan menciptakan goal dari daerah belakang gawang (menyerupai permainan hoki)

\section{Metode Penelitian}

Metode penelitian yang digunakan dalam penelitian ini yaitu metode eksperimen. Dalam penelitian faktor yang dicobakan dan merupakan variabel bebas adalah latian soccer like games untuk diketahui pengaruhnya terhadap peningkatan keterampilan passing sepakbola yang bertindak sebagai variabel terikat. Penelitian ini dilakukan agar dapat memperoleh gamabaran yang jelas sesuai dengan tujuan yang telah ditetapkan.

Desain yang digunakan dalam penelitian ini adalah Pretest-Posttest Control Group Design. Dengan desain penelitian ini diberi tes awal untuk mengukur kondisi awal.

Desain Penelitian

\section{$01 \times 02$}

O1 : tes awal passing permainan sepakbola

$\mathrm{O} 2$ : tes akhir passing permainan sepakbola

$\mathrm{X} \quad$ : Soccer Like Game

Dalam penelitian ini, populasi yang diambil adalah 30 siswa kelas VII C SMP Negeri 1 Sukahaji Kabupaten Majalengka. Penulis mengambil sampel sebanyak 15 orang dari populasi yang di ambil dari siswa kelas VII C SMP Negeri 1 Sukahaji Data tersebut diperoleh pada awal eksperimen sebagai data awal dan pada akhir eksperimen sebagai data akhir. Tujuannya 
agar dapat mengetahui pengaruh hasil perlakuan dan perbedaannya yang merupakan tujuan akhir dari eksperimen. Tes yang pertama dilakukan adalah tes kemampuan passing yang akan diberikan peneliti pada testee.

\section{Hasil dan Pembahasan}

Berdasarkan hasil penelitian yang telah dilakukan didapat data tes awal dan akhir pada sampel yang diberikan perlakukan pembelajaran soccer like games (eksperimen). Untuk lebih jelasnya tertera pada Tabel 4.1 dibawah ini.

Tabel 4.1

Nilai Perhitungan Rata-Rata dan Hasil Simpangan Baku Tes awal dan Tes akhir keterampilan passing

\begin{tabular}{|c|c|c|}
\hline $\begin{array}{c}\text { Keterampilan } \\
\text { passing }\end{array}$ & Nilai Simpangan baku & $\begin{array}{c}\text { Nilai Rata- } \\
\text { rata }\end{array}$ \\
\hline Hasil tes awal & 9,53 & 2,61 \\
\hline Hasil tes akhir & 12,33 & 2,82 \\
\hline
\end{tabular}

Dari tabel di atas dapat dilihat bahwa nilai rata-rata kelompok pembelajaran soccer like games (eksperimen) mengalami peningkatan pada akhir masa eksperimen, pembelajaran sepakbola pada pembelajaran soccer like games menunjukan hasil tes awal keterampilan dasar passing dengan rata-rata sebesar 9,53 dengan simpangan baku sebesar 2,61 mengalami peningkatan pada saat tes akhir dengan rata-rata sebesar 12,33dengan serta simpangan baku sebesar 2,82.

\section{Pengolahan dan Analisis Data}

Uji Normalitas Passing

Tabel 4.2

Hasil Pengujian Normalitas Liliefors Tes Keterampilan Passing

\begin{tabular}{|l|c|c|c|}
\hline \multicolumn{1}{|c|}{$\begin{array}{c}\text { Tes Keterampilan } \\
\text { Passing }\end{array}$} & L Hitung & L Tabel & Kesimpulan \\
\hline Kelompok & & & \\
eksperimen Tes & 0,1117 & 0,22 & Normal \\
Awal Tes Akhir & 0,1722 & 0,22 & Normal \\
\hline
\end{tabular}

Berdasarkan Tabel 4.2 di atas diketahui nilai $\mathrm{L}_{\text {tabel }}$ untuk tes keterampilan passing dari daftar sebesar 0,22 kemudian nilai $\mathrm{L}_{\text {hitung }}$ untuk kelompok Soccer Like Games sebagai eksperimen adalah sebesar 0,1117 dan tes akhir eksperimenL $L_{\text {hitung }}$ sebesar 0,1722 dan nilai $\mathrm{L}_{\text {hitung }}$ normal. Berdasarkan pada tabel eksperimen didapat data untuk tes awal 0,1117 ( $\left.\mathrm{L}_{\text {hitung }}\right)<0,22$ ( $\left.\mathrm{L}_{\text {tabel }}\right)$ maka data normal, untuk tes akhir eksperimen memiliki data $0,1722\left(\mathrm{~L}_{\text {hitung }}\right)<0,22\left(\mathrm{~L}_{\text {tabel }}\right)$ 
maka data normal., untuk tes akhir kelompok eksperimen memiliki data $0,142\left(\mathrm{~L}_{\text {hitung }}\right)<0,22$ $\left(\mathrm{L}_{\text {tabel}}\right)$ maka data normal.

\section{Uji Homogenitas}

Tabel 4.3Tabel Hasil Pengujian Kesamaan Dua Variansi Tes Passing

\begin{tabular}{|c|c|c|c|c|c|}
\multicolumn{7}{|c}{$\mathrm{A}=0,05-2=28 \mathrm{dk}=30$} \\
\hline Tes Awal & Kelompok & Variansi (S2) & $\mathrm{F}_{\text {hitung }}$ & $\mathrm{F}_{\text {tabel }}$ & Kesimpulan \\
\hline Tes Akhir & Kelompok Konsperimen & 6,83 & 1,12 & & Homogen \\
\cline { 3 - 5 } 2,48 & 7,95 & 1,06 & & Homogen \\
\hline
\end{tabular}

Dari tabel 4.3 diketahui bahwa hasil uji variansi tes awal eksperimen adalah 6,83 sedang passing kelompok eksperimen adalah 7,95. Dari tabel diatas penentuan homogenitas dengan kriteria H0: Data homogen dan H1: Data tidak homogen. Kriteria pengujiannya yaitu Jika $F_{\text {hitung }}<F_{\text {tabel }}$ maka $\mathrm{H} 0$ diterima (data homogen), sedangkan jika $F_{\text {hitung }}>F_{\text {tabel }}$ maka $\mathrm{H} 0$ ditolak (data tidak homogen). Hasil pengujian kesamaan dua variansi tes awal di atas, diketahui bahwa hasil Fhitung tes awal keterampilan passing dari soccer like games (eksperimen) dengan pembelajaran konvensional adalah Fhitung $(1,01)<$ Ftabel 2,48 maka data tersebut. Kemudian pengujian kesamaan dua variansi tes akhir di atas, diketahui bahwa hasil $\mathrm{F}$ hitung tes akhir keterampilan passing dari soccer like games eksperimen < Ftabel 2,48 .

\section{Pengujian Hipotesis Penelitian}

Tabel 4.4Tabel Uji Hipotesis Rata-rata $(\mu)$ : Uji Satu Pihak Tes Keterampilan Passing

\begin{tabular}{|c|c|c|c|}
\hline & Thitung & Ttabel & Kesimpulan \\
\hline Kelompok eksperimen & 2,870 & 2,048 & Signifikan \\
\hline
\end{tabular}

Dari tabel 4.4 diatas diketahui $\mathrm{T}_{\text {hitung }}$ tes keterampilan passing dari Soccer Like Games di dapat $\mathrm{T}_{\text {hitung }}=2,870>\mathrm{T}_{\text {tabel }}(2,048)$ maka $\mathrm{H}_{1}$ diterima dan Ho ditolak (data signifikan), dengan demikian terdapat pengaruh yang signifikanpada Soccer Like Games terhadap keterampilan dasar sepakbola.

\section{Uji selisih peningkatan}

Tabel 4.5

Tabel Uji Hipotesis Kesamaan Dua Rata-rata $(\mu)$ : Uji Dua Pihak Tes Keterampilan Passing

\begin{tabular}{|c|c|c|c|}
\hline Kelompok & Thitung & Ttabel & Kesimpulan \\
\hline eksperimen & 5,88 & 2,048 & Signifikan \\
\hline
\end{tabular}


Dari tabel 4.5 diatas diketahui $\mathrm{T}_{\text {hitung }}$ dari eksperimen maka Ho ditolak dan $\mathrm{H}_{1}$ diterima, dengan demikian terdapat perbedaan pembelajaran Soccer Like Games terhadap Keterampilan passing pada pembelajaran sepakbola.

\section{Pembahasan Hasil Penelitian}

Berdasarkan penelitian yang telah dilakukan dilapangan bahwa penerapan soccer like games terhadap peningkatan keterampilan passing dalam permainan sepakbola, dimana dalam penelitian ini keterampilan dasar yang diteliti yaitu passing dapat berjalan dengan baik dan lancar. Dimulai dari tahap awal sampai tahap akhir proses pembelajaran dapat berjalan kondusif.

Dari hasil pengolahan dan analisis data yang telah dilakukan oleh penulis, didapatkan hasil dan temuan dilapangan sebagai berikut:

1. Berdasarkan hasil dan analisis data didapatkan temuan bahwa penerapan soccer like games memberikan pengaruh yang signifikan terhadap keterampilan dasar sepakbola. Pada prosesnya soccer like games berisikan permainan-permainan yang hampir menyerupai permainan sepakbola pada umumnya, sehingga dalam proses nya siswa mengalami proses pembelajaran keterampilan sepakbola tanpa disadari oleh mereka.

2. Temuan dilapangan, siswa sangat begitu antusias dalam mengikuti proses pembelajaran. Hal tersebut muncul dikarenakan siswa bisa mengeksplorasi semua keterampilan gerak yang mereka miliki serta siswa tidak terlalu lama untuk menunggu melakukan tugas gerak dan waktu pembelajaran tidak terbuang karena menunggu giliran untuk melakukuan tugas gerak. Pada dasarnya pembelajaran Soccer like games merupakan bentuk modifikasi yang dibuat dari permainan sepakbola dimana tujuannya untuk membantu siswa untuk meningkatkan pemahaman terhadap materi ajar dan memiliki intelektualitas yang baik serta memiliki keterampilan gerak dan lebih memudahkan siswa teribat dalam pembelajaran sepakbola. Dalam penelitian inti penulis bermaksud untuk mengembangkan keterampilan dasar sepakbola melalui soccer like games.

Menurut Lutan (Bahagia, 2011) Modifikasi dalam penjas bertujuan agar 1. Siswa memperoleh kepuasan dalam mengikuti pelajaran. 2. Meningkatkan kemungkinan keberhasilan dalam berpartisipasi 3. Siswa melakukan pola gerak secara benar". Soccer like games merupakan salah bentuk dari modifikasi tersebut. 


\section{Kesimpulan}

Dari beberapa penemuan yang telah dipaparkan sebelumnya, dapat disimpulkan bahwa penerapan soccer like games memberikan pengaruh yang signifikan terhadap peningkatan keterampilan dasar sepakbola pada pembelajaran sepakbola. Maka dari itu penerapan olahraga yang dimodifikasi sangat perlu dilakukan dalam proses pembelajaran agar siswa termotivasi untuk melakukan tugas gerak serta mampu mengembangkan keterampilan anak lebih cepat dan efektif dalam proses pembelajaran. Hal ini perlu dilakukan karena proses pembelajaran di era sekarang terlihat begitu monoton dan mengakibatkan siswa bosan sehingga dibutuhkan pembelajaran yang variatif dan inovatif seperti soccer like games.

\section{Daftar Pustaka}

Abduljabar, B. (2010). Manajemen Pendidikan Jasmani dan Olahraga. Bandung.

Abduljabar, B. (2011). Pedagogi Olahraga. Bandung.

Abduljabar, B. dan Darajat, K. N. (2010). Modul Aplikasi Statistika Dalam Penjas. Bandung: UPI Bandung.

Arikunto, S. (2006). Prosedur Penelitian Suatu Pendekatan Praktik. Jakarta: PT. Rineka Cipta.

Arikunto, S. (2009). Manajemen Penelitian. Jakarta: PT. Rineka Cipta.

Bahagia, Y. (2011). Fasilitas dan Perlengkapan Pendidikan Jasmani. Bandung: FPOK UPI

Bahagia, Y. (2011). Permainan Invasi. Bandung: FPOK UPI

Benny A. P. (2009). Model Desain Sistem Pembelajaran. Jakarta: PT. Dian Rakyat.

BSNP. (2006). Standar Kompetensi dan Kompetensi Dasar SMP/Mts. Jakarta: Badan Standar Nasional Pendidikan.

Dimyati dan Mudjiono. (2006). Belajar dan Pembelajaran. Jakarta: Rineka Cipta

Hamalik, O. (2003). Kurikulum dan Pembelajaran. Bandung: Bumi Aksara.

Husdarta \& Yudha, M. S. (2000). Belajar dan pembelajaran. Jakarta:

Juliantine, T. (2012). Belajar dan Pembelajaran Penjas. Bandung: FPOK Universitas Pendidikan Indonesia.

Juliantine, dkk. (2013). Modul Model-model Pembelajaran Pendidikan Jasmani.Bandung.

Lutan, R. (2000). Manajemen Penjaskes. Jakarta: Depdiknas.

Luxbacher, Joe. (2004). SEPAKBOLA: Taktik dan Teknik Bermain. Jakarta: PT Raja Grafindo Persada Mahendra, A. (2007). Modul Mata Kuliah Dual Mode Teori belajar mengajar Motorik. Bandung: FPOK UPI.

Mahendra, A. (2009). Asas dan Falsafah Pendidikan Jasmani. Bandung.

Mendiknas. (2005). Undang-undang Standar Nasional Pendidikan (SNP). Jakarta:

Peraturan Pemerintah Nomor 20 tahun 2003. Penerbit Fokusmedia.

Mielke, D. (2007). Dasar-Dasar Sepak Bola. Bandung : Human Kinetics

Nurhasan. (2007). Tes dan pengukuran keolahragaan. Bandung: Jurusan Pendidikan Kepelatihan Fakultas Olahraga dan Kesehatan Universitas Pendidikan Indonesia.

Sanjaya, W. (2005). Pembelajaran dalam Implementasi Kurikulum Berbasis Kompetisi. Jakarta: Kencana Prenada Media Group.

Saputra, Y. M. (2007). Pendidikan Jasmani Dan Olahraga. Bandung: MKU UPI Bandung.

Sucipto. (2000). Sepakbola. Jakarta: Depdiknas

Sugiyono. (2013). Metode Penelitian Pendidikan, Pendekatan Kuantitatif Kualitatif dan R\&D. Bandung. ALFABETA

Suherman, A. (2009). Revitalisasi Pengajaran Dalam Pendidikan Jasmani. Bandung: Bintang Warli Artika

Usli, L.W., Hermanu, E., dan Imanudin, I. 2008. Pelatihan Cabang Olahraga Sepakbola. Bandung: FPOK UPI. 